\title{
EGG DESTRUCTION BY MALES IN THE WESTERN GREBE AND CLARK'S GREBE
}

\author{
FLOYD E. HAYES, DYLAN G. TURNER, NATHAN D. ZIMMERLY, and MANUEL \\ B. PERALTA, Department of Biology, Pacific Union College, 1 Angwin Ave., Angwin, \\ California 94508; floyd_hayes@yahoo.com; turnerdylan27@gmail.com; nathan. \\ zimmerly@gmail.com; bernardoson@hotmail.com
}

BRYAN J. MCINTOSH, 5226 4th St. \#35, Kelseyville, California 95451; bryan_m_95451@yahoo.com

MYCHAL E. HELLIE, Department of Biology, Pacific Union College, 1 Angwin Ave., Angwin, California 94508; mehellie@puc.edu

ABSTRACT: Destruction of eggs in nests of a bird's own species has been reported in many species of birds, including three species of grebes of the family Podicipedidae. We report for the first time four incidents of egg destruction by Western Grebes (Aechmophorus occidentalis) and three by Clark's Grebes (Aechmophorus clarkii) in mixed breeding colonies at Clear Lake, Lake County, California, from 2014 to 2017. All incidents occurred during the late stage of nesting within a colony. Five incidents of egg destruction occurred at three recently vacated nests in which the previous eggs had been removed by mammalian predators $<24$ hours earlier; the other two incidents occurred at nests with an unknown history. Egg destruction was perpetrated only by males. The eggs may have been destroyed to usurp nests or to prevent brood parasitism or cuckoldry. Because none of the eggs or adults were marked and no tissue samples were taken, it was impossible to be certain of the relationships among adults and eggs, and whether egg destruction was intraspecific or interspecific.

Many species of birds, across a broad spectrum of taxonomic groups, destroy eggs in other birds' nests or even in their own nests. Some birds routinely destroy eggs of their own species, which is a form of infanticide (Hrdy 1979, Veiga 2000). Others, such as several wrens of the family Troglodytidae (Brewer 2010), routinely destroy the eggs of other species. The circumstances under which egg destruction occurs and its proximate causes are complex, and numerous hypotheses for it have been proposed. These may be classified into broad categories such as consumption, resource competition, and sexual selection (e.g., Hrdy 1979, Spooner et al. 1996, Veiga 2000).

Intraspecific egg destruction has been reported in at least three species of grebes (family Podicipedidae). The eggs of the Great Crested Grebe (Podiceps cristatus) are sometimes kicked unintentionally out of a nest (Simmons 1955), but Konter (2008a,b) reported three instances of two eggs intentionally kicked out of a nest and an egg pushed out of a nest during a fight with a conspecific. McAllister (1958) reported finding many Eared Grebe (P. nigricollis) eggs removed from nests and destroyed by a small hole pecked into each egg, which she attributed to conspecifics, but over two years of observation never saw a grebe pecking an egg. Perkins et al. (2005) reported several instances of eggs deliberately removed from nests by incubating Horned Grebes (P. auritus), and Summers et al. (2009) reported a nest destroyed by a conspecific.

In this article we provide details representing the first reports of intraspecific and interspecific egg destruction in the Western Grebe (Aechmophorus 


\section{EGG DESTRUCTION BY THE WESTERN AND CLARK'S GREBES}
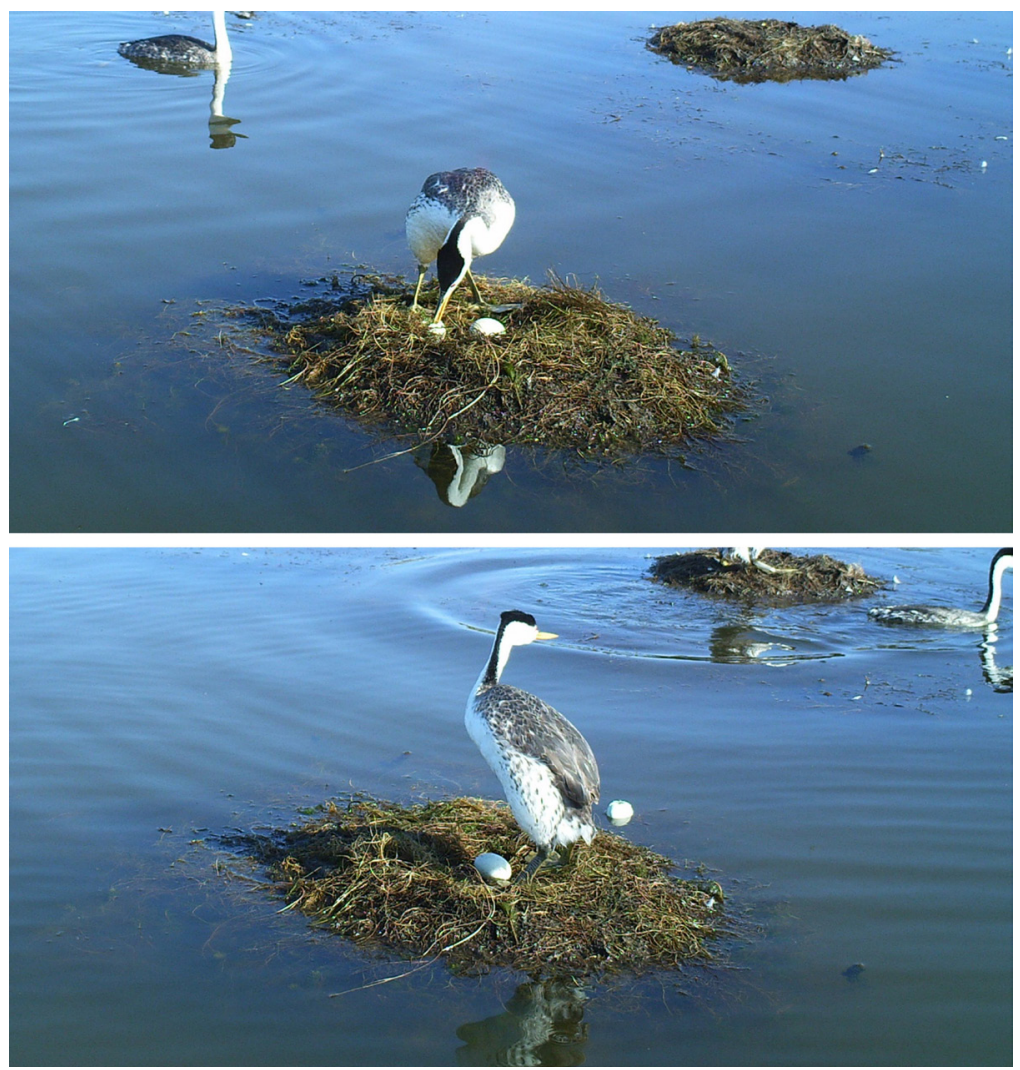

Figure 1. A male Clark's Grebe pecking at an egg (above) and the punctured egg floating in the water beside the nest 6.7 minutes later (below) at the north end of Clear Lake on 1 September 2014 (see incidents 1 and 2 for further details). Photos by motion-activated camera.

occidentalis) and Clark's Grebe (A. clarkii). We describe the conditions under which egg destruction occurs, evaluate its frequency of occurrence, identify the sex of perpetrators, and attempt an explanation.

\section{STUDY SITE AND METHODS}

\section{Study Site and Subjects}

Clear Lake is a large $\left(180 \mathrm{~km}^{2}\right)$, relatively shallow (depth $\leq 18 \mathrm{~m}$ ), and highly eutrophic lake in Lake County, northern California $\left(39^{\circ} 01^{\prime} \mathrm{N}, 122^{\circ}\right.$ $46^{\prime}$ W). Two major wetlands are associated with the lake: its largest tributary, Rodman Slough, at the northwest end of the lake, and its outlet, Cache Creek, which meanders through Anderson Marsh at the southeast end of 
the lake. The natural history of the lake and the anthropogenic footprint on it have been summarized by Suchanek et al. (2003).

The Western Grebe and Clark's Grebe are socially monogamous species (Storer and Nuechterlein 1992) that nest together and occasionally hybridize in mixed colonies at Clear Lake and its associated wetlands (Feerer and Garrett 1977, Robison et al. 2015, Hayes and Turner 2017, Hayes et al. 2018). The grebes build floating nests of aquatic vegetation, which are attached to emergent vegetation along the shore or submerged vegetation in open water up to $1 \mathrm{~km}$ from shore, along the margins of the lake and its associated wetlands where the water is shallow.

\section{Methods}

We recorded data on the incidence of egg destruction incidentally while studying the grebes' breeding ecology. During the breeding seasons (AprilSeptember) from 2010 to 2017, we searched for grebe colonies at Clear Lake and its associated wetlands once or twice (rarely three times) during most weeks, averaging 21 trips per year (range 15-32). We usually searched for grebe nests from a canoe (most days, 5-25 km/day) or motorboat (1-3 times per year), although a few areas close to a road were searched by vehicle or by foot during each trip. To estimate the rate of natural and anthropogenic disturbances, including egg destruction, we recorded the amount of time that we spent observing grebe activities in active breeding colonies with eggs.

From 2014 to 2017 we deployed up to six motion-activated cameras (Bushnell Trophy Cam Bone Collector RTAP Night Vision and Bushnell Trophy Cam HD Aggressor No Glow) within active colonies to study the grebes' breeding activities and the fate of their eggs. Each camera was bolted to a U-channel post, which was pushed by hand into the soft bottom of the lake, and aimed at a focal nest with one or more eggs 3-5 m away. For each camera we recorded the number of hours from the time when a grebe first returned to a focal nest after the camera was placed to the time of the final photo when a grebe was on a nest with one or more eggs.

Subsequently, we scrutinized photos of activities at grebe nests for evidence of egg destruction. In photos documenting egg destruction we attempted to identify the pertinent species of each individual by its plumage and soft-part coloration, and the sex of each individual by its bill size, which is notably longer and stouter in the male (Ratti and McCabe 1983, Storer and Nuechterlein 1985, 1992, Hartman et al. 2016) and easily distinguished in photos. None of the eggs or adults were marked and no tissue samples were taken.

\section{RESULTS}

The number of grebe nests recorded per year ranged from 888 to 5936 , with a mean of 3073 (SD $=1988, n=8$ years). We observed only one incident of egg destruction, by a Western Grebe, during 283 hours of observation of active grebe colonies. Our cameras documented six additional incidents at four nests, including three by Western Grebes and three by Clark's Grebes, during 11,309 hours of monitoring at 122 nests, for an average of one 
incident per 1885 hours. To provide the full context for each incident, we briefly summarize the history of activities at each nest.

\section{Incidents 1 and 2}

A camera recorded two incidents of a male Clark's Grebe tossing an egg off a nest within 1.5 hours on 1 September 2014, in a colony of 4721 nests at the northwest end of Clear Lake. The colony had been active for $>2.5$ months (first two nests found on 13 June). At 10:08 on 31 August, an American Mink (Neovison vison) consumed two eggs previously incubated by a male Clark's Grebe and a female Western Grebe. A pair of Western Grebes subsequently took turns resting on the nest, and the female laid an egg between 14:08 and 14:17. A second egg was laid by an unknown female (not visible in a photo) between 18:52 and 20:50. The following morning (1 September) at 07:13 a male Clark's Grebe was incubating until it was replaced by a female Western Grebe at 07:26, when both birds were briefly on the nest. The male returned to the nest to incubate between 07:29 (female still on nest) and 07:46 (male only on nest). At 07:58 the male Clark's Grebe stood up and appeared to be grasping an egg, which was apparently tossed off the nest (tossing not photographed), and resumed incubating the remaining egg until it stood up at 08:01, when only one egg was visible, and the female replaced the male on the nest. Subsequent photos revealed the egg was missing and not merely covered with nesting material.

The female remained on the nest, was briefly joined by the male at 08:52, and departed the nest at 08:53, revealing a second recently laid egg on the nest. The male returned to incubate at 08:56 and departed at 09:12. At 09:22 the male returned, pecked a hole in an egg, and tossed the egg into the water, where it floated near the nest for at least 9 minutes (Figure 1). The male preened itself on the nest until it departed at 09:30, when the female arrived. Both birds took turns incubating the remaining egg throughout the day (six shifts for the male, seven for the female), during which the male repeatedly added vegetation to the nest and defended the nest from passing grebes, until the last photo of the day with the male on the nest at 17:13. The next photo, taken at 07:36 the following morning (2 September), revealed the female behind the empty nest and a broken egg floating about $1 \mathrm{~m}$ away in the water. Unfortunately the camera did not document how the egg was broken and wound up in the water. The nest was empty when we arrived at 08:08 and moved the camera to another nest. It is uncertain whether the male that attacked the eggs was the same male that incubated the eggs, maintained the nest, and chased away passing grebes.

\section{Incident 3}

On 3 July 2016, the colony of 799 nests at Rodman Slough had been active for more than 1 month (the first 37 nests were found on 10 June). At 15:33 Turner observed a Western Grebe of undetermined sex toss an egg off a nest about $7 \mathrm{~m}$ away from us. The egg was the only one on the nest. The history of the nest was unknown. 

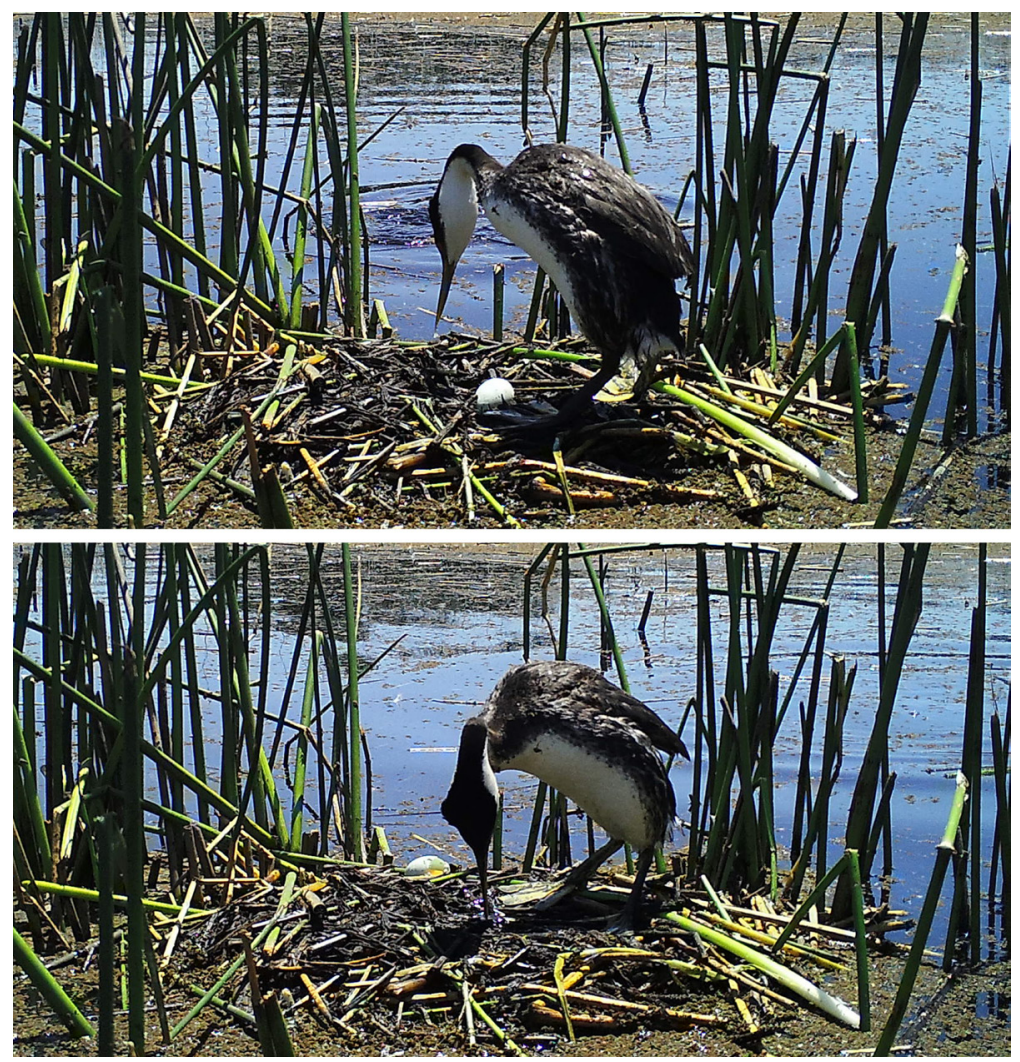

Figure 2. A male Western Grebe standing above an egg (above) and the punctured egg at the edge of the nest 31 seconds later (below) at Anderson Marsh, Clear Lake, on 23 June 2017 (see incident 7 for further details). Photos by motion-activated camera.

Incidents 4 and 5

Also at Rodman Slough, a male Western Grebe destroyed two eggs in one nest within a period of 7.5 hours on 5 July 2016. At 22:25 the previous night a Northern Raccoon (Procyon lotor) preyed upon two eggs on the nest. The nest was unattended until 09:28, when a Western Grebe was in the water and facing the nest while another Western Grebe was swimming away. Only 18 seconds later an egg appeared on the nest while two Western Grebes were in the water, facing the nest, and a third Western Grebe, apparently a female by its small bill, was swimming away with a wake behind it, indicating it had just deposited the egg and departed the nest. Just 23 seconds later a male Western Grebe climbed up onto the nest and appeared to grab the egg with its beak, and 17 seconds later the egg was missing while the male was still on the nest and another grebe was arriving at the nest.

Subsequently a pair of Western Grebes copulated on the empty nest 
four times between 12:45 and 15:57. At 16:08, an egg appeared on the nest with a female Clark's Grebe standing above it, as though it had just been laid. At 16:58 the intact egg was partially visible underneath a female Western Grebe sitting on the nest while a male Western Grebe was in the water facing the nest. Just 17 seconds later the egg was still partially visible under the female Western Grebe but it was clearly smashed with the yolk exposed, while the male Western Grebe, presumably the perpetrator, was in the water at the edge of the nest and facing the egg on the nest. The nest was not attended by grebes that evening, and at 22:13 a raccoon inspected the empty nest. During the subsequent 10 days both species copulated on the nest multiple times and multiple were eggs laid, raccoons preying on them repeatedly, but none were incubated by grebes.

\section{Incident 6}

On 5 August 2016, again at Rodman Slough, one of our cameras photographed a male Clark's Grebe kicking an egg off a nest. At 03:38 on 3 August, a raccoon preyed upon three eggs that a pair of Clark's Grebes had been incubating the previous day. Subsequently Clark's Grebes copulated on the nest at 06:38, an egg was laid by an unknown grebe species between 08:36 and 08:39, Western Grebes copulated on the nest three times from 11:36 to 17:04, and Clark's Grebes copulated on the nest at 20:02. However, the egg was never incubated. The following day, 4 August, a female Western Grebe and male Clark's Grebe copulated on the nest three times from 14:01 to 14:33 and a second egg was laid by an unidentified grebe between 18:32 and 18:52, but that egg was not incubated either. On 5 August, a pair of Western Grebes attended the nest with two eggs from 07:49 to 07:50, then a pair of Clark's Grebes attended the nest intermittently, often sitting on the eggs as though they were incubating, from 09:30 to $15: 17$. At 12:56 a male Clark's Grebe was standing on a nest with its left foot between two eggs. Just 1 minute and 43 seconds later only one egg was visible on the nest and the grebe's left foot had moved toward the left, suggesting that it kicked the egg off the nest, intentionally or unintentionally. The second egg disappeared at 15:39, apparently knocked off the nest by a basking Red-eared Slider (Trachemys scripta elegans). A male Western Grebe and female Clark's Grebe copulated on the nest four times from 15:52 to 16:11. At 19:07, a female Clark's Grebe laid an egg on the nest and a pair of Clark's Grebes took turns incubating it throughout 6 August and the morning of 7 August, after which we moved the camera to another nest.

\section{Incident 7}

On 23 June 2017 at Anderson Marsh, in a colony of 2054 nests, a male Western Grebe smashed an egg and flicked it aside. The colony had been active for $>2$ months (first eggs and newly hatched chicks found on 7 May; the mean incubation period is 24 days, Storer and Nuechterlein 1992). After we aimed a camera at a nest with a single egg at 11:47, a pair of Western Grebes took turns incubating the egg, with ten shifts by the female and three by the male. At 14:03 the female departed the nest and at 14:04 the male climbed up on the nest, but instead of resuming incubation the male smashed the egg with its bill and flicked the egg to the edge of the nest, where yolk 
oozed out of a hole in the egg (Figure 2). After rolling the broken egg into the center of the nest at 14:08, the male sat on the egg until it departed the nest at 14:18. The female returned to the nest at 14:19 and sat on the broken egg until 14:27. After briefly leaving the nest, the female returned at 14:29, pushed the egg to the edge of the nest, and sat down on the nest until it departed at 14:36. The male arrived at 14:55, tossed the broken egg off the nest at 15:00, and departed at 15:04. The male returned again to the empty nest from 15:24 to 15:32 and the female returned from 15:33 to at least 15:41, when the camera's batteries died.

\section{DISCUSSION}

This study demonstrates that egg destruction, which was intentional in at least six of the seven incidents, occurs rarely in breeding Aechmophorus grebes. Our rate of one incident per 1885 camera-hours is an imprecise measurement of frequency because eggs were often not visible even when present, being covered with nesting material by an adult. Others were taken by predators or vanished under unknown circumstances. Some nests attached to submerged vegetation in open water frequently drifted in and out of view of the cameras, and the cameras varied in their sensitivity to motion, often failing to capture significant events resulting in the disappearance of eggs on a nest. Because egg destruction takes only a few seconds at most and is easily overlooked, it probably occurs more frequently than our few observations suggest, but it is not a common behavior.

Although Aechmophorus grebes sometimes engage in reproductive activities at night (Hayes et al. 2018), all incidents of egg destruction occurred during daylight. Five incidents occurred at three recently vacated nests from which the previous eggs had been removed by mammalian predators $<24$ hours earlier (incidents 1-2 and 4-6). The remaining two incidents ( 3 and 7 ) occurred at nests with an unknown history. All incidents occurred during a late stage of nesting within a colony. These observations suggest that the eggs most likely to be destroyed are those freshly laid on a recently vacated nest late in the nesting season. When eggs disappear from nests because of predation, rain, or being blown ashore by strong winds, multiple pairs of grebes often copulate on the nests (copulation occurs only on nests), and females often dump eggs on them; sometimes the eggs are subsequently incubated but often they are not (Hayes and Turner 2017, Hayes et al. 2018, this study). The individuals engaging in such frenetic reproductive activities may be unmated individuals seeking a mate, mated pairs seeking a new nest after recently losing a clutch of eggs, mated individuals seeking opportunities for extra-pair copulations, or females dumping surplus eggs.

Egg destruction was perpetrated only by males, which presumably benefit from the behavior more than females whose eggs were victimized. Previous reports of intraspecific egg destruction in other species of grebes did not report the sex of perpetrators (McAllister 1958, Perkins et al. 2005, Konter 2008a,b, Summers et al. 2009).

The consumption hypothesis postulates that the perpetrator consumes the eggs to obtain nutrients. Several species of birds, especially in the families Laridae and Corvidae, routinely cannibalize the eggs of conspecifics (e.g., 
Pettingill 1939, Parsons 1971, Yom-Tov 1975, Trail et al. 1981, Chardine and Morris 1983). Such cannibalism may occur most frequently when food resources are limited (Hayward et al. 2014). However, we never observed grebes consuming the contents of destroyed eggs and neither did the observers of intraspecific egg destruction in other species of grebes (McAllister 1958, Perkins et al. 2005, Konter 2008a,b, Summers et al. 2009).

The competition hypothesis proposes that destroying neighbors' eggs may drive away competitors for limited resources, such as food or nest sites (Picman 1977a, b, Vehrencamp 1977, Belles-Isles and Picman 1986, Heinsohn 1988, Pribil and Picman 1991, 1992, Kattan 2016). However, Aechmophorus grebes nest in dense colonies with closely spaced nests (Storer and Nuechterlein 1992). At Clear Lake we recorded up to 433 nests per hectare with an average of $2.9 \mathrm{~m}$ between nests, but some nests were $<1 \mathrm{~m}$ apart (Hayes et al. 2018, unpubl. data). Although we often observed aggression between pairs of grebes on neighboring nests and occasionally observed grebes stealing nesting material from neighboring nests, eggs were destroyed only on recently vacated nests. If the grebes intended to drive away competitors for limited resources, they should be expected to destroy eggs on new nests as well.

The sexual-selection hypothesis suggests that males or polyandrous females destroy eggs of potential mates to terminate their current nesting cycle, make them receptive to mating again, and subsequently mate with them (Stephens 1982, Freed 1986, Brown and Brown 1988, Kermott et al. 1991, Veiga 1993). However, in incidents 1 and 2 an incubating pair never copulated during at least the first 9 hours after egg destruction. Copulations occurred after egg destruction in incidents 4 and 5, but the circumstances suggest other reasons for destroying eggs (see below).

The nest-usurpation hypothesis postulates that eggs of a conspecific are destroyed so the nest can be acquired by a perpetrator for its own use, a scenario most likely when nest sites are limited. For example, several cavity-nesting species of birds destroy the eggs of conspecifics to usurp their nests (Hotta 1994, Bonebrake and Beissinger 2010, Kasahara et al. 2014). Similarly, nests that are costly to build and maintain may also be usurped. Grebes invest considerable time and energy constructing large and bulky floating nest platforms, which require the addition of new nesting material each day to prevent them from dissipating (Fjeldså 2004). McAllister (1958) attributed the destruction of Eared Grebe eggs to pairs of grebes aggressively taking over other grebes' nests that already contained eggs. In incident 4 , an egg a female Western Grebe laid in a recently vacated nest was tossed from the nest by a male Western Grebe $<30$ seconds later. Afterward a pair of Western Grebes copulated on the nest four times, suggesting that the first egg was tossed off the nest so that the pair could usurp the nest.

The anti-parasitism hypothesis proposes that eggs of conspecific brood parasites are removed from a nest to reduce the cost of raising the offspring of other individuals (Emlen and Wrege 1986). For example, the European Starling (Sturnis vulgaris) routinely removes the eggs of conspecific brood parasites from its nests (Stouffer et al. 1987, Lombardo et al. 1989, Romagnano et al. 1990, Moksnes and Elvertø 2006). Lyon and Everding (1996) reported a high rate of intraspecific brood parasitism in the Eared Grebe 
and a higher rate of egg loss from parasitized nests than from nonparasitized nests. Lyon and Everding (1996) reinterpreted McAllister's (1958) report of eggs tossed from nests as grebes ridding their nests of eggs dumped by brood-parasitizing conspecifics. Brood parasitism is common in Aechmophorus grebe colonies, with clutches often exceeding ten eggs. Bent (1919) reported up to 16 eggs in a single nest, and we have documented up to 30 eggs in a nest at Clear Lake (Hayes et al. unpubl. data). The grebes routinely incubate clutches of up to ten eggs, but larger clutches are rarely incubated (Hayes et al. unpubl. data). In incident 5, a female Clark's Grebe laid an egg on a nest in which a pair of Western Grebes had copulated four times during the previous 3.5 hours. The dumped egg was destroyed within 1 hour by a male Western Grebe, suggesting that the latter recognized a parasitic egg in its nest.

The anti-cuckoldry hypothesis posits that males destroy eggs in their own nest when the paternity of their partner's eggs is in doubt, as has been reported in several species of birds (Freed 1987, Osorio-Beristain and Drummond 2001, Chen et al. 2008, García-Navas et al. 2013). In incidents 1 and 2 the eggs of a male Clark's Grebe and female Western Grebe were destroyed by a predator. Later in the day a pair of Western Grebes attended the nest and two eggs were laid, although no copulations occurred. The following day a male Clark's Grebe and female Western Grebe took turns incubating the eggs, one of which was soon destroyed by the male. After a female laid another egg, one of the remaining two eggs was also destroyed by a male. Given the lack of copulations with its mate on the nest the male may have destroyed eggs suspected of being fertilized by another male. These incidents could also be interpreted as a pair usurping a nest with two eggs whose destruction they delayed.

The pathology hypothesis considers egg destruction a displacement behavior with no adaptive value, perhaps occurring when a nest is disturbed by the presence of humans or a mate is lost (Mountfort 1958, Chardine and Morris 1983, Boves et al. 2011). Six of the seven incidents we describe, however, were documented by stationary, nonthreatening motion-activated cameras when no humans were present. Five of the incidents occurred the day after a predator took an egg the previous night, but the cameras gave no evidence of predation on an adult grebe or of a predator during the day when the egg was destroyed.

In conclusion, male Aechmophorus grebes rarely destroy eggs freshly laid in recently vacated nests during the late stage of nesting within a colony, possibly to usurp the nests for their own use or to prevent brood parasitism or cuckoldry by other grebes. Because none of the eggs or adults were marked and no tissue samples were taken, we cannot be certain of the relationships among adults and eggs, and whether the egg destruction was intraspecific or interspecific.

\section{ACKNOWLEDGMENTS}

We followed all applicable ethical guidelines for the use of birds in research, including those presented in the Ornithological Council's "Guidelines to the use of Wild Birds in Research." Funding was generously provided by 
Audubon California, the Luckenbach Trustee Council, the National Audubon Society, the National Fish and Wildlife Foundation, the National Oceanographic and Atmospheric Administration, Pacific Union College, and the Redbud Audubon Society. We thank K. Kyle, G. Lanham, D. Loggins, and M. Waits for managing the project, B. Hayes, M. Hayes, and A. Wyrick for assistance with field work, and B. Lyon and an anonymous reviewer for reviewing the manuscript.

\section{LITERATURE CITED}

Belles-Isles, J.-C., and Picman, J. 1986. House Wren nest destroying behavior. Condor 88:190-193; doi 10.2307/1368914.

Bent, A. C. 1919. Life histories of North American diving birds, order Pygopodes. U. S. Natl. Mus. Bull. 107:1-380.

Bonebrake, T. C., and Beissinger, S. R. 2010. Predation and infanticide influence ideal free choice by a parrot occupying heterogeneous tropical habitats. Oecologia 1063:385-393; doi 10.1007/s00442-010-1566-8.

Boves T. J., Buehler D. A., and Boves, N. E. 2011. Conspecific egg destruction by a female Cerulean Warbler. Wilson J. Ornithol. 123:401-403; doi 10.1676/10151.1.

Brewer, D. 2001. Wrens, Dippers and Thrashers. Christopher Helm, London.

Brown, C. R., and Brown, M. B. 1988. The costs and benefits of egg destruction in colonial Cliff Swallows. Auk 105:737-748.

Chardine, J. W., and Morris, R. D. 1983. Herring Gull males eat their own eggs. Wilson Bull. 95:478-478.

Chen, T.-C., Lin, Y.-S., Deng, P.-L., and Ding, T.-S. 2008. Male Pheasant-tailed Jacanas commit infanticides to avoid cuckoldry when paternity of eggs is doubtful. J. Nat. Hist. 42:47-48; doi 10.1080/00222930802389817.

Emlen, S. T., and Wrege, P. H. 1986. Forced copulations and intra-specific parasitism: Two costs of social living in the White-fronted Bee-eater. Ethology 71:2-29.

Feerer, J. L., and Garrett, R. L. 1977. Potential Western Grebe extinction on California lakes. Cal.-Nev. Wildl. Trans. 13:80-89.

Fjeldså, J. 2004. The Grebes. Oxford Univ. Press, Oxford, England.

Freed, L. A. 1986. Territorial takeover and sexually selected infanticide in tropical House Wrens. Behav. Ecol. Sociobiol. 19:197-206.

Freed, L. A. 1987. Prospective infanticide and protection of genetic paternity in tropical House Wrens. Am. Nat 130:948-954; doi 10.1086/284758.

García-Navas, V. J., Ortego, J., Ferrer, E. S., and Sanz, J. J. 2013. Feathers, suspicions, and infidelities: An experimental study on parental care and certainty of paternity in the Blue Tit. Biol. J. Linnean Soc. 109:552-561; doi 10.1111/ bij. 12079.

Hartman, C. A., Ackerman, J. T., Eagles-Smith, C. A., and Herzog, M. P. 2016. Differentiating sex and species of Western Grebes (Aechmophorus occidentalis) and Clark's Grebes (Aechmophorus clarkii) and their eggs using external morphometrics and discriminant function analysis. Waterbirds 39:13-26; doi 10.1675/063.039.0103.

Hayes, F. E., and Turner, D. G. 2017. Copulation behavior in the Western Grebe (Aechmophorus occidentalis) and Clark's Grebe (A. clarkii). Waterbirds 40:168-172; doi 10.1675/063.040.0209.

Hayes, F. E., Turner, D. G., Zimmerly, N. D., and Peralta, M. B. 2018. Nocturnal courtship, copulation, and egg laying in the Western Grebe (Aechmophorus occidentalis) and Clark's Grebe (Aechmophorus clarkii). J. Ethol. 35:65-75; doi 10.1007/s10164-017-0526-8. 
Hayward, J. L., Weldon, L. M., Henson, S. M., Megna, L. C., Payne, B.G., and Moncrieff, A. E. 2014. Egg cannibalism in a gull colony increases with sea surface temperature. Condor 116:62-73; doi 10.1650/CONDOR-13-016-R1.1.

Heinsohn, R. G. 1988. Inter-group ovicide and nest destruction in cooperatively breeding White-winged Choughs. Anim. Behav. 36:1856-1858; doi 10.1016/ S0003-3472(88)80134-9.

Hotta, M. 1994. Infanticide in Little Swifts taking over costly nests. Anim. Behav. 47:491-493; doi 10.1006/anbe.1994.1070.

Hrdy, S. B. 1979. Infanticide among animals: A review, classification and examination of the implications for the reproductive strategies of females. Ethol. Sociobiol. 1:13-40; doi 10.1016/0162-3095(79)90004-9.

Kasahara, S., Yamaguchi, Y., Mikami, O. K., and Ueda, K. 2014. Conspecific egg removal behaviour in Eurasian Tree Sparrow Passer montanus. Ardea 102:47-52; doi 10.5253/078.102.0110.

Kattan, G. H. 2016. Heterospecific infanticidal behavior by Southern House Wrens (Troglodytes aedon musculus) suggests nest site competition. Wilson Bull. 128:899-903.

Kermott, L. H., Johnson, L. S., and Merkle, M. S. 1991. Experimental evidence for the function of mate replacement and infanticide by males in a north-temperate population of House Wrens. Condor 93:630-636; doi 10.2307/1368194.

Konter, A. 2008a. Seasonal evolution of colonial breeding in the Great Crested Grebe Podiceps cristatus: A four years' study at Lake IJssel. Ardea 96:13-24.

Konter, A. 2008b. Colonial nesting in the Great Crested Grebe Podiceps cristatus (Linné 1758): Research results from a colony on the Dutch IJsselmeer in comparison to other studies on colonial nesting in the species. Ferrantia 56:1-119.

Lombardo, M. P., Power, H. W., Stouffer, P. C., Romagnano, L. C., and Hoffenberg, A. S. 1989. Egg removal and intraspecific brood parasitism in the European Starling (Sturnus vulgaris). Behav. Ecol. Sociobiol. 24:217-223; doi 10.1007/ BF00295201.

Lyon, B. E., and Everding, S. 1996. High frequency of conspecific brood parasitism in a colonial waterbird, the Eared Grebe Podiceps nigricollis. J. Avian Biol. 27:238-244; doi 10.2307/3677228.

McAllister, N. M. 1958. Courtship, hostile behavior, nest-establishment and egg laying in the Eared Grebe (Podiceps caspicus). Auk 75:290-311; doi $10.2307 / 4081975$.

Moksnes, A., and Elvertø, P.-A. 2006. Host responses against natural and experimental conspecific brood parasitism in the Starling Sturnus vulgaris. Ornis Fennica 83:139-144.

Mountfort, G. 1958. Portrait of a Wilderness: The Story of the Coto Doñana Expeditions. Hutchinson, London.

Osorio-Beristain, M., and Drummond, H. 2001. Male boobies expel eggs when paternity is in doubt. Behav. Ecol. 12:16-21; doi 10.1093/oxfordjournals. beheco.a000373.

Parsons, J. 1971. Cannibalism in Herring Gulls. Br. Birds 64:228-237.

Perkins, A. J., Hancock, M. H., Butcher, N., and Summers, R.W. 2005. Use of time-lapse video cameras to determine causes of nest failure of Slavonian Grebes Podiceps auritus. Bird Study 52:159-165; doi 10.1080/00063650509461386.

Pettingill, O. S., Jr. 1939. History of one hundred nests of Arctic Tern. Auk 56:420428; doi 10.2307/4078793.

Picman, J. 1977a. Destruction of eggs by the Long-billed Marsh Wren (Telmatodytes palustris palustris). Can. J. Zool. 55:1914-1920.

Picman, J. 1977b. Intraspecific nest destruction in the Long-billed Marsh Wren, Telmatodytes palustris palustris. Can. J. Zool. 55:1997-2003.

Pribil, S., and Picman, J. 1991. Why House Wrens destroy clutches of other birds: 
A support for the nest site competition hypothesis. Condor 93:184-185; doi $10.2307 / 1368624$.

Pribil, S., and Picman, J. 1992. Behavioral mechanisms preventing filial ovicide in House Wrens. Behav. Ecol. 3:352-359; doi 10.1093/beheco/3.4.352.

Ratti, J. T., and McCabe, T. R. 1983. Morphological divergence between Western Grebe color morphs. J. Field Ornithol. 54:424-426.

Robison, K. M., Anderson, D. W., and Robison, R. E. 2015. Brood size and nesting phenology in Western Grebe (Aechmophorus occidentalis) and Clark's Grebe (Aechmophorus clarkii) in northern California. Waterbirds 38:99-105; doi 10.1675/063.038.0113.

Romagnano, L., Hoffenberg, A. S., and Power, H. W. 1990. Intraspecific brood parasitism in the European Starling. Wilson Bull. 102:279-291.

Simmons, K. E. L. 1955. Studies on Great Crested Grebes. Avicult. Mag. 61:3-13, 93-102, 131-146, 181-201, 294-316.

Spooner, A., Pribil, S., and Picman, J. 1996. Why do Gray Catbirds destroy eggs in nests of other birds? Experimental tests of alternative hypotheses. Can. J. Zool. 74:1688-1695; doi 10.1139/z96-186.

Stephens, M. L. 1982. Male takeover and possible infanticide by a female Northern Jacana. Anim. Behav. 30:1253-1254; doi 10.1016/S0003-3472(82)80219-4.

Storer, R. W., and Nuechterlein, G. L. 1985. An analysis of plumage and morphological characters of the two color forms of the Western Grebe (Aechmophorus). Auk 102:102-119; doi 10.2307/4086826.

Storer, R. W., and Nuechterlein, G. L. 1992. Western Grebe (Aechmophorus occidentalis)/Clark's Grebe (Aechmophorus clarkii), in The Birds of North America (A. Poole, P. Stettenheim, and F. Gill, eds.), no. 26. Acad. Nat. Sci., Philadelphia; doi 10.2173/bna.26a.

Stouffer, P. C., Kennedy, E. D., and Power, H. W. 1987. Recognition and removal of intraspecific parasite eggs by Starlings. Anim. Behav. 35:1583-1584; doi 10.1016/S0003-3472(87)80040-4.

Suchanek, T. H., Richerson, P. J., Nelson, D. C., Eagles-Smith, C. A., Anderson, D. W., Cech J. J. Jr., Zierenberg, R., Schladow, G., Mount, J. F., McHatton, S. C., Slotton, D. G., Webber, L. B., Swisher, B. J., Bern, A. L., and Sexton M. 2003. Evaluating and managing a multiply-stressed ecosystem at Clear Lake, California: A holistic ecosystem approach, in Managing for Healthy Ecosystems (D. J. Rapport, W. L. Lasley, D. E. Rolston, N. O. Nielsen, C. O. Qualset, and A. B. Damania, eds.), pp. 1239-1271. Lewis Publ., Boca Raton, FL.

Summers, R. W., Mavor, R. A., and Hancock, M. H. 2009. Correlates of breeding success of Horned Grebes in Scotland. Waterbirds 32:265-275; doi 10.1675/063.032.0206.

Trail, P. W., Strahl, S. D., and Brown, J. L. 1981. Infanticide in relation to individual and flock histories in a communally breeding bird, the Mexican Jay (Aphelocoma ultramarina). Am. Nat. 118:72-82; doi 10.1086/283802.

Vehrencamp, S. L. 1977. Relative fecundity and parental effort in communally nesting anis, Crotophaga sulcirostris. Science 197:403-405; doi 10.1126/ science.197.4301.403.

Veiga, J. P. 1993. Prospective infanticide and ovulation retardation in free-living House Sparrows. Anim. Behav. 45:43-46; doi 10.1006/anbe.1993.1005.

Veiga, J. P. 2000. Infanticide by male birds, in Infanticide by Males and Its Implications (C. P. van Schaik and C. H. Janson, eds.), pp. 198-220. Cambridge Univ. Press, Cambridge, England.

Yom-Tov, Y. 1975. Synchronization of breeding and intraspecific interference in the Carrion Crow. Auk 92:778-785; doi 10.2307/4084788. 